\title{
Mid-term outcomes of posterior stabilized total knee arthroplasty in severe osteoarthritis
}

\section{Dizin Ileri derecede osteoartritinde bağ kesen total diz artroplastisinin orta dönem sonuçları}

\author{
Omer Faruk KILICASLAN*1ㅁ, Mehmet Ali TOKGOZ² $\square$, Ali Bulent BAZ1 $\square$, Serdar AKALIN³ $\square$
}

${ }^{1}$ Antalya Training And Research Hospital, Department of Orthopaedics and Traumatology, Antalya/TURKEY ${ }^{2}$ Ankara Keçiören Training And Research Hospital, Department of Orthopaedics and Traumatology, Ankara/TURKEY ${ }^{3}$ Antalya Bilim University, Antalya/TURKEY

\begin{abstract}
Aim: The purpose of this study was to reveal mid-term outcomes by retrospectively investigating patients who underwent total knee arthroplasty with a posterior stabilized design (PS).

Material and methods: The study included a total of 68 knees of 52 patients with completed follow-up data who underwent PS total knee arthroplasty due to a diagnosis of primary or secondary osteoarthritis. The 52 patients comprised

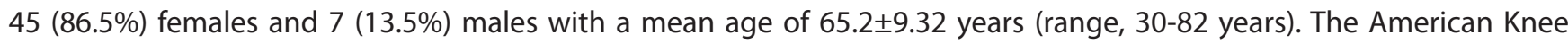
Society criteria were adopted for assessment of patient knee scores and functional knee scores. The Total Knee Prosthesis Radiological Evaluation criteria were applied for radiological evaluation of the patients.

Results: The mean follow-up period of the patients was $32.1 \pm 9.85$ months (range: 18-60 months) and the Knee Society Scores were 41.5 (range: 26 - 58) preoperatively, and 84.3 (range: 51 - 97) postoperatively. The mean preoperative and postoperative range of motion was $88.2^{\circ}$ (range: $60^{\circ}-100^{\circ}$ ), and $106.7^{\circ}$ (range: $90^{\circ}-120^{\circ}$ ), respectively. Two-stage revision surgery was applied to one patient due to deep infection. No cases of aseptic loosening were observed. Implant survivorship was observed as $98.8 \%$, and excellent and good results according to the functional knee score were reported as $41.1 \%$, and $32.3 \%$, respectively.
\end{abstract}

Conclusion: Positive patient outcomes were obtained with the use of PS total knee arthroplasty in patients with severe osteoarthritis and there was no evidence of significant implant survival loss in mid-term follow-up.

Keywords: Knee osteoarthritis; total knee arthroplasty; posterior stabilized design

Corresponding author*: Ömer Faruk KILIÇASLAN, Antalya Training And Research Hospital, Department of Orthopaedics and Traumatology, Antalya/TURKEY

E-mail: kilicaslanfaruk@hotmail.com

ORCID: 0000-0001-6716-4542

Recevied: 03/04/2021 accepted: 02/06/2021

Doi: $10.18663 /$ tjcl.909044 


\section{Öz}

Amaç: Bu çalışmanın amacı, posterioru stabilize eden tasarım (PS) ile total diz artroplastisi uygulanan hastaları retrospektif olarak inceleyerek orta dönem sonuçlarını ortaya çıkarmaktı.

Gereç ve Yöntemler: Çalışmaya primer veya sekonder osteoartrit tanısı nedeniyle PS total diz artroplastisi uygulanan

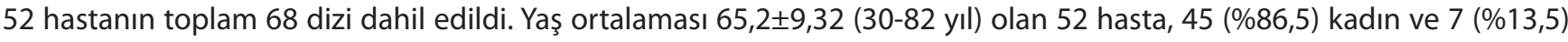
erkekten oluşuyordu. hastaların diz ve fonksiyonel skorlarının değerlendirmek için Amerikan Diz Derneği kriterleri benimsendi. Hastaların radyolojik değerlendirilmesinde Total Diz Protezi Radyolojik Değerlendirme kriterleri uygulandı.

Bulgular: Hastaların ortalama takip süresi 32,1 \pm 9,85 ay (dağııım: 18-60 ay) ve Knee Society Skorları ameliyat öncesi 41,5 (dağılım: 26 - 58), ameliyat sonrası ise 84,3 (aralık: 51 - 97) idi. Ortalama preoperatif ve postoperatif hareket açıkığı sırasıyla $88,2^{\circ}$ (aralık: $60^{\circ}-100^{\circ}$ ) ve $106,7^{\circ}$ (aralık: $90^{\circ}-120^{\circ}$ ) idi. Bir hastaya derin enfeksiyon nedeniyle iki aşamalı revizyon cerrahisi uygulandı. Aseptik gevşeme vakası gözlenmedi. İmplant sağkalımı \%98,8 olarak gözlendi ve fonksiyonel diz skoruna göre mükemmel ve iyi sonuçlar sırasıyla $\% 41,1$ ve $\% 32,3$ olarak bildirildi.

Sonuç: Şiddetli osteoartriti olan hastalarda PS total diz artroplastisi kullanımı ile pozitif hasta sonuçları elde edildi ve orta dönem takiplerinde implant sağkalımında önemli bir kayıp olduğuna dair kanıt yoktu.

Anahtar kelimeler: Diz osteoartriti; total diz artroplastisi; posterior stabilize tasarım

\section{Introduction}

One of the most fervent and long-term controversies in orthopedic surgery is the role of the posterior cruciate ligament $(\mathrm{PCL})$ in total knee arthroplasty (TKA). Excellent long-term clinical outcomes of TKA in designs of the cruciate-sacrificing, cruciate-substituting, and cruciate-retaining types have made it difficult for surgeons to decide [1]. Retention or resection of the PCL depends on the surgeon's experience and familiarity with implant placement instruments and the condition of the PCL observed intraoperatively. Although debate continues on many issues, it has been recommended that PCL be sacrificed when posterolateral instability, significant coronal deformity, inflammatory arthritis, extensor mechanism deficiency, flexion contracture or PCL insufficiency is detected $[2,3]$.

In cases when the PCL is sacrificed, the posterior stabilized (PS) design is traditionally used. In vitro studies have demonstrated that physiological posterior femoral translation over the tibia during flexion (femoral rollback) and reproducing the natural axial rotation of the femur (screw-home mechanism) provide an improvement in the function of the extensor mechanism and increased knee flexion. Compared to a healthy knee joint, the above-mentioned joint functions are decreased after TKA, although PS designs provide better femoral rollback and greater knee flexion than ligament preserving designs [4].

In a cadaver study, the significant contribution of the $\mathrm{PCL}$ in providing medial-lateral stability was demonstrated [5]. The aforementioned finding supports the idea that in knees with advanced varus or valgus deformity, better mediolateral balance could be achieved by sacrificing the PCL [6]. Cruciatepreserving knee prosthesis designs applied to patients with coronal deformities $>15^{\circ}$ have been reported to be associated with postoperative pain and revision surgeries. In addition, in knees with fixed flexion contracture, symmetrical joint space is obtained more easily with ligament-cutting designs [7].

Although there are studies reporting the clinical and functional results of PS TKA designs, new studies are still needed due to the controversies in the literature. The aim of the current study was to reveal the mid-term outcomes by retrospectively investigating patients who underwent total knee arthroplasty with a posterior stabilized design.

\section{Material and methods}

Approval for the study was granted by the Local Ethics Committee (Date:20.06.2013, number: 21/3).The study was conducted in compliance with the principles of the Declaration of Helsinki. A retrospective review was made of patients who underwent total knee arthroplasty due to knee osteoarthritis between December 2008 and June 2012. The patients included in the study were treated with posterior stabilized implants due to grade IV osteoarthritis according to Kellgren-Lawrence grades and had completed an 18-month follow-up period.

Demographic and clinical data were obtained from patient charts, medical records, and operation notes, including gender, age at surgery, etiology, follow-up duration, number of blood transfusion units, and complications. Range of 
motion measurements, functional evaluation using the Knee Society Score (Knee and Function Score) [8], and radiological measurements were performed preoperatively and at the final follow-up examination. Patients were excluded from the study if implant designs other than PS TKA had been used, if there were oncological-hematological surgical etiologies, or if data were incomplete.

All surgical procedures were performed using a medial parapatellar approach. Standard distal femoral and tibial cuts were made, laminar spreaders were used to assess extension gaps, and provisional soft tissue releases were performed in full extension. Femoral rotational alignment was obtained according to the epicondylar axis, usually $3^{\circ}$ of external rotation from the posterior condylar line. The knee was fine balanced utilizing soft tissue releases for varus and valgus knees, followed by the shift and resect technique for severely varus knees. None of the patients underwent patellar joint surface replacement. Patellar osteophyte removal and patellar denervation were performed in all patients. Fixation of tibial and femoral components was achieved with bone cement. At the end of the procedure, a hemovac drain was inserted before the closure of the wound and a bulky compression dressing was used to all patients. Antibiotic prophylaxis and venous thromboembolism prophylaxis were administered in accordance with current guidelines $[9,10]$.

After the removal of the compression dressing and hemovac drain at the 24th hour of postoperative period, antiembolic stockings were worn on both legs and patients were mobilized with full weight-bearing with the aid of a walker or crutches. Isometric quadriceps exercises were started under the supervision of a physiotherapist in the early postoperative period and the patients were discharged after the knee joint flexion was achieved above $90^{\circ}$ and full extension with a supervised home rehabilitation program. At the third postoperative week, strengthening and range of motion exercises were performed more aggressively for achieving full range of motion. After the sixth week, strengthening and functional exercises were added to enable the patient to walk without assistance.

Radiological evaluation was made based on weight-bearing anteroposterior and lateral views of the knee. In alignment analysis, the valgus degrees of the knee were indicated as negative numerals, and varus as positive. The location of radiolucent lines was evaluated based on the Knee Society Roentgenographic Evaluation System [11]. In the postoperative radiological evaluation, radiolucent lines were examined in millimeters for the relationship of the prosthesis with the bone surface, fixation quality, and signs of loosening. For radiolucent field evaluation, the femoral and tibial components were evaluated on anteroposterior and lateral radiographs.

Component positions were evaluated on the basis of 4 angles: the lateral distal femoral angle (LDFA, a angle), which was measured between the anatomic axis of the femur and a tangential line to the distal condyles of the femoral prosthesis; the medial proximal tibia angle (MDTA, $\beta$ angle), which lies between the anatomic axis of the tibia and a tangential line to the plateau of the tibial prosthesis; the flexion-extension femoral angle (FEFA, $\gamma$ angle), which is between a line through the midshaft of the femur and the neutral line of the femoral prosthesis; and the tibial slope angle (TSA, $\sigma$ angle), which is the angle between a line through the midshaft of the tibia and a tangential line to the tibial prosthesis (Figure 1).

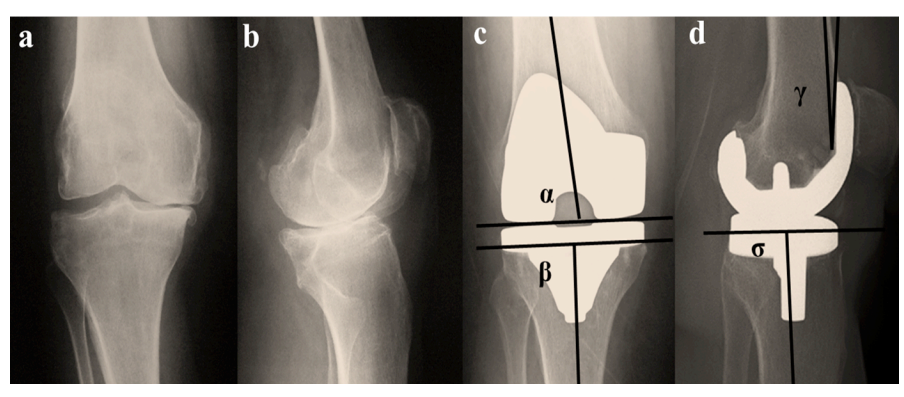

Figure 1. A 63-year-old female patient was operated on with the diagnosis of primary osteoarthritis in the left knee.Preoperative $(a, b)$ and postoperative $(\mathrm{c}, \mathrm{d}) \mathrm{AP}$ and lateral radiographs.Showing the four angles $(a, \beta, \gamma, \sigma)$ where component positions are evaluated $(c, d)$. The follow-up period was 21 months. The postoperative knee score was 83 , and the functional score was 80 . There were no postoperative complications. Knee and functional scores were found to be good.

\section{Statistical Analysis}

Statistical analysis was performed using IBM SPSS Statistics for Windows, Version 23.0 software (IBM Corp., Armonk, NY, USA). Categorical variables were given as number ( $n$ ) and percentage (\%), and continuous variables as mean \pm standard deviation (SD) values. The Chi-square test was used for the comparison of categorical variables. The conformity of continuous variables to normal distribution was evaluated using visual (histogram and probability graphs) and analytical methods (Kolmogorov-Smirnov / Shapiro-Wilk tests). The Paired Samples t-test and the Wilcoxon rank test were used to compare data in accordance with the normality testing. A value of $p<0.05$ was considered to be statistically significant. 


\section{Results}

The evaluation was made of 52 with a mean age of $65.2 \pm 9.32$ years (range: $30-81$ years) and mean follow-up period of 32.1 \pm 9.85 months (range:18-60 months). Patient characteristics and baseline demographics are presented in Table 1.During the 68 knee arthroplasty surgeries performed, the need for blood transfusion occurred in 14 procedures, and the mean number of transfusion units was calculated as $0.41 \pm 0.72$. When stability in the mediolateral plane was evaluated preoperatively, it was determined as $\leq 5^{\circ}$ in 26 knees (38.2\%), $6-9^{\circ}$ in 35 knees (51.4\%), $10-14^{\circ}$ in 5 knees (7.4\%), and $>15^{\circ}$ in 2 knees (2.9\%).

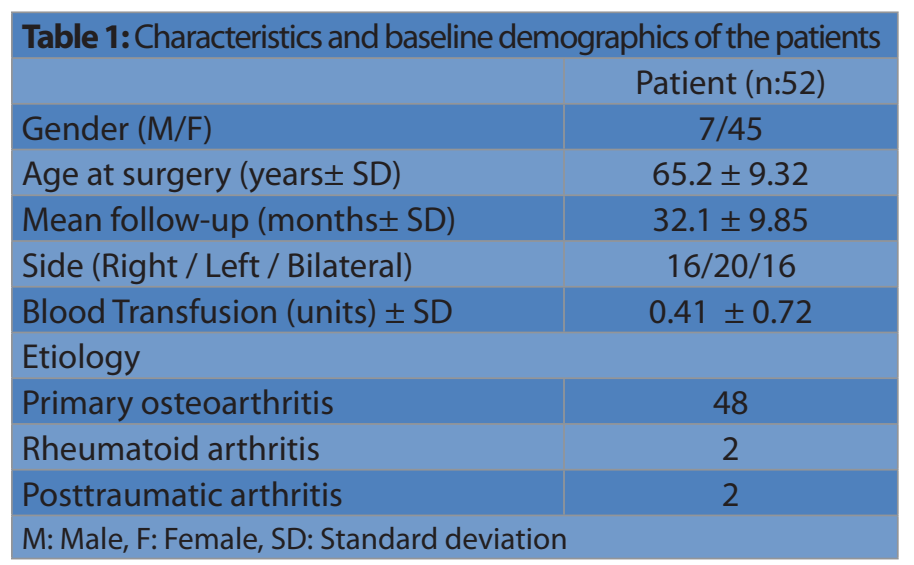

The mean mechanical tibiofemoral angle was $5.36^{\circ} \pm 5.22^{\circ}$ (range: $-22^{\circ}$ to $+20^{\circ}$ ) preoperatively, and was restored to mean $-3.16^{\circ} \pm 1.72^{\circ}$ (range: $-7^{\circ}$ to $0^{\circ}$ ) postoperatively. Flexion contracture was mean $6.76^{\circ} \pm 1.24^{\circ}$ (range, $0^{\circ}-15^{\circ}$ ) preoperatively and flexion range was $88.2^{\circ} \pm 10.7^{\circ}$ (range, $60^{\circ}-$ $\left.100^{\circ}\right)$. Postoperatively, the mean range of motion of the knee increased to $106.7^{\circ} \pm 7.5^{\circ}$ (range, $90^{\circ}-120^{\circ}$ ). Postoperative restricted range of motion that required manipulation was observed in four patients at an average of 4 weeks.

The mean angle measurements were alpha angle $90.9^{\circ} \pm 2.52^{\circ}$ $\left(86^{\circ}-100^{\circ}\right)$, beta angle $90^{\circ} \pm 1.20^{\circ}\left(88^{\circ}-94^{\circ}\right)$, gamma angle $1.2^{\circ}$ $\pm 1.28^{\circ}\left(0^{\circ}-6^{\circ}\right)$, and sigma angle $90^{\circ} \pm 2.2^{\circ}\left(82^{\circ}-95^{\circ}\right)$. None of the patients had a flexion contracture at the final follow-up. The detailed radiographic results are presented in Table 2.

The mean the Knee Society Score [8] improved from preoperative $41.5 \pm 8.83$ (range: $26-58$ ) to $84.3 \pm 9.14$ (range: 51 97) postoperatively ( $p: 0.001$ ), and the Knee Society function score increased from $38.8 \pm 17.2$ (range: $10-70$ ) to $77.7 \pm 14.8$ (range: $45-100)$ following PS TKA ( $p: 0.001)$. The increases in both the Knee Society total knee and knee function scores were determined to be statistically significant (Table 2).

\begin{tabular}{|c|c|c|c|}
\hline & Preoperative & Final follow-up & $p$ value \\
\hline KSS (knee) & $41.5 \pm 8.5$ & $84.3 \pm 9.1$ & 0.001 \\
\hline KSS (function) & $38.8 \pm 17.2$ & $77.7 \pm 14.9$ & 0.001 \\
\hline ROM (flexion/extension) & $88.2 \pm 10.7$ & $106.7 \pm 7.5$ & 0.001 \\
\hline Coronal alignment of knee & $5.36 \pm 5.22$ & $-3.16 \pm 1.72$ & 0.017 \\
\hline \multicolumn{4}{|l|}{ Component evaluation } \\
\hline $\begin{array}{l}\text { Radiological line } \\
<2 \mathrm{~mm} \\
>2 \mathrm{~mm}\end{array}$ & - & $\begin{array}{c}4(5.8 \%) \\
0(0 \%)\end{array}$ & \\
\hline $\operatorname{LDFA}(a)^{\circ}$ & - & $90.9 \pm 2.52(86-100)$ & \\
\hline $\operatorname{MDTA}(\beta)^{\circ}$ & - & $90 \pm 1.20(88-94)$ & \\
\hline FEFA $(\gamma)^{\circ}$ & - & $1.2 \pm 1.28(0-6)$ & \\
\hline $\operatorname{TSA}(\sigma)^{\circ}$ & - & $90 \pm 2.2(82-95)$ & \\
\hline
\end{tabular}

Prosthesis survival was evaluated as $98.5 \%$ after a mean followup of 32 months (18-60 months). Superficial skin infection in 5 (7.3\%) patients and local serous wound discharge in 2 patients (2.9\%) was detected in the early postoperative period. Infection developed in 1 patient (1.4\%) after eighteen months. Superficial infections and serous discharge were treated with wound dressing and empiric oral antibiotherapy due to negative bacterial wound culture. The late-stage infection was treated with two-stage revision surgery. During the follow-up period, no femoral component lysis was observed in any patient. A radiolucent area $<4 \mathrm{~mm}$ was detected in the tibial component in 6 cases. There was no progression of osteolysis observed in the follow-up of these cases, and revision surgery was not performed in any patient due to aseptic loosening. None of 
the patients developed deep vein thrombosis, pulmonary embolism, or complications related to the tourniquet.

\section{Discussion}

The aim of this study was to present the mid-term results of posterior stabilized total knee arthroplasty applied because of severe osteoarthritis. The study results demonstrated that prosthesis survival was $98.5 \%$ after a mean follow-up of 32 months. Quality of life and functional scores improved significantly after surgery.

Total knee arthroplasty continues to give excellent clinical results in the relief of complaints caused by degenerative osteoarthritis. A total of 11,606 total knee arthroplasties were evaluated by Rand et al. in terms of overall survival, and it was reported that successful results were observed in $96 \%$ at five years and in $91 \%$ at ten years. When subgroup analysis was applied to the ten-year survival rate results, a rate of $91 \%$ was determined for the designs that retained the posterior cruciate ligament, and 76\% for the posterior stabilized implants [12]. In a study by Serna-Berna et al. of patients with a minimum tenyear follow-up, cruciate-retaining (268 subjects) and posteriorstabilized (211 subjects) primary total knee arthroplasty designs were compared, and no statistically significant difference was determined between overall survival rates [13].

Long-term success in total knee arthroplasty can be achieved by ensuring proper alignment. Malalignment results in the need for revision operations due to loosening and instability in the early and late periods. Lotke et al. reported that the most favorable angle is valgus $3^{\circ}-7^{\circ}$ [14]. It was stated by Ritter et al. that the neutral axis of the leg could be achieved with a tibiofemoral angle of $5^{\circ}-7^{\circ}$ [15]. In the current study, the mean tibiofemoral angle was corrected from preoperative $5.4^{\circ}$ varus to $3.1^{\circ}$ valgus.

After total knee prosthesis, at least $90^{\circ}$ range of motion of the knee should be provided, and no loss of extension or flexion contracture is accepted. Preoperative range of motion is the most important factor determining the postoperative range of motion [16]. In a study evaluating knee prostheses flexion angles with a posterior stabilized design, mean flexion was reported to be $103.1^{\circ}$ at the end of five years [13]. In a study presenting the long-term results of single-radius, posteriorstabilized total knee arthroplasty, the mean maximum flexion angle was reported to be $129^{\circ}$ (range, $95^{\circ}-150^{\circ}$ ) [17]. Preoperative flexion in the current study was $88.2^{\circ}$, and this improved to $106.7^{\circ}$ postoperatively.
The main limitations of this study were the retrospective design with a limited number of patients and relatively short follow-up time. Other limitations of the study were the heterogeneity of etiological reasons and the absence of a control group. However, the data obtained from this study could provide preliminary information for prospective control studies to be planned.

The results of this study demonstrated that in patients with severe osteoarthritis, PS total knee prosthesis provided $91.3 \%$ excellent and good knee scores, and $73.5 \%$ excellent and good functional scores in patients with severe osteoarthritis. Moreover, prosthesis survival was found to be $98.5 \%$ after a mean follow-up of 32 months.

\section{Conclusion}

The current study demonstrated that the use of PS total knee arthroplasty in patients with severe osteoarthritis could provide satisfactory outcomes with appropriate patient selection, adequate preoperative preparation, and careful surgical technique, and there was no evidence of significant implant survival loss in mid-term follow-up.

\section{Declaration of conflict of interest}

The authors received no financial support for the research and/or authorship of this article. There is no conflict of interest

\section{References}

1. Pagnano MW, Cushner FD, Scott WN. Role of the posterior cruciate ligament in total knee arthroplasty. J Am Acad Orthop Surg 1998; 6: 176-87.

2. Song SJ, Park CH, Bae DK. What to Know for Selecting CruciateRetaining or Posterior-Stabilized Total Knee Arthroplasty. Clin Orthop Surg. 2019; 11: 142-50.

3. Matziolis $\mathrm{G}$, Mehlhorn $\mathrm{S}$, Schattat $\mathrm{N}$ et al. How much of the $\mathrm{PCL}$ is really preserved during the tibial cut? Knee surgery, sports traumatology, arthroscopy : official journal of the ESSKA 2012; 20: 1083-6.

4. Bignozzi S, Zaffagnini S, Akkawi I et al. Three different cruciatesacrificing TKA designs: minor intraoperative kinematic differences and negligible clinical differences. Knee surgery, sports traumatology, arthroscopy : official journal of the ESSKA 2014; 22: 3113-20.

5. Mihalko WM, Miller C, Krackow KA. Total knee arthroplasty ligament balancing and gap kinematics with posterior cruciate ligament retention and sacrifice. Am J Orthop (Belle Mead NJ) 2000; 29: 610-6. 
6. Baldini A, Castellani L, Traverso F, Balatri A, Balato G, Franceschini V. The difficult primary total knee arthroplasty: a review. Bone Joint J 2015; 97: 30-9.

7. Su EP. Fixed flexion deformity and total knee arthroplasty. J Bone Joint Surg Br. 2012; 94: 112-5.

8. Scuderi GR, Sikorskii A, Bourne RB, Lonner JH, Benjamin JB, Noble PC. The Knee Society Short Form Reduces Respondent Burden in the Assessment of Patient-reported Outcomes. Clin Orthop Relat Res 2016; 474: 134-42.

9. Eikelboom JW, Karthikeyan G, Fagel N, Hirsh J. American Association of Orthopedic Surgeons and American College of Chest Physicians guidelines for venous thromboembolism prevention in hip and knee arthroplasty differ: what are the implications for clinicians and patients? Chest 2009; 135: 513-20.

10. Bosco JA, Bookman J, Slover J, Edusei E, Levine B. Principles of Antibiotic Prophylaxis in Total Joint Arthroplasty: Current Concepts. J Am Acad Orthop Surg 2015; 23: 27-35.

11. Ewald FC. The Knee Society total knee arthroplasty roentgenographic evaluation and scoring system. Clin Orthop Relat Res 1989; 248: 9-12.
12. Rand JA, Trousdale RT, Ilstrup DM, Harmsen WS. Factors affecting the durability of primary total knee prostheses. The Journal of bone and joint surgery American volume 2003; 85: 259-65.

13. Serna-Berna R, Lizaur-Utrilla A, Vizcaya-Moreno MF, Miralles Muñoz FA, Gonzalez-Navarro B, Lopez-Prats FA. CruciateRetaining vs Posterior-Stabilized Primary Total Arthroplasty. Clinical Outcome Comparison With a Minimum Follow-Up of 10 Years. J Arthroplasty 2018; 33: 2491-5. E

14. Lotke PA, Ecker ML. Influence of positioning of prosthesis in total knee replacement. The Journal of bone and joint surgery American volume 1977; 59: 77-9.

15. Ritter MA, Faris PM, Keating EM, Meding JB. Postoperative alignment of total knee replacement. Its effect on survival. Clin Orthop Relat Res 1994; 299: 153-6.

16. Ritter MA, Harty LD, Davis KE, Meding JB, Berend ME. Predicting range of motion after total knee arthroplasty. Clustering, loglinear regression, and regression tree analysis. The Journal of bone and joint surgery American volume. 2003; 85: 1278-85.

17. Chang MJ, So S, Park CD, Seo JG, Moon YW. Long-term follow-up and survivorship of single-radius, posterior-stabilized total knee arthroplasty. J Orthop Sci. 2018; 23: 92-6. 